ENTREPRENEURSHIP AND SUSTAINABILITY ISSUES

ISSN 2345-0282 (online) http://jssidoi.org/jesi/

2020 Volume 7 Number 4 (June)

http://doi.org/10.9770/jesi.2020.7.4(19)

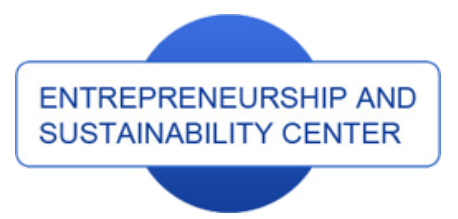

Publisher

http://jssidoi.org/esc/home

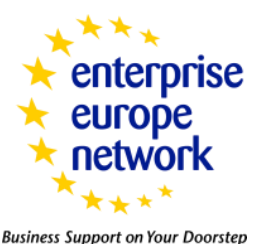

Business Support on Your Doorstep

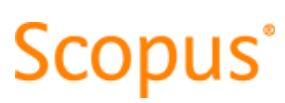

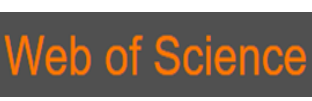

1) Clarivate

Analytics

\title{
DEVELOPMENT AND VALIDATION OF A SAFETY CLIMATE SCALE FOR UNITED ARAB EMIRATES OIL AND GAS INDUSTRIES*
}

\author{
Mohamed Ali Al Mazrouei ${ }^{1}$, Khalizani Khalid ${ }^{2}$, Ross Davidson ${ }^{3}$ \\ ${ }^{1,2,3}$ Abu Dhabi University, College of Business, United Arab Emirates \\ E-mails: ${ }^{1}$ emarrati@hotmail.com $;{ }^{2}$ drkhalizanikhalid@gmail.com $;{ }^{3}$ ross.davidson@adu.ac.ae
}

Received 18 November 2019; accepted 15 March 2020; published 30 June 2020

\begin{abstract}
This study aims to develop and validate a safety climate scale for United Arab Emirates (UAE) oil and gas industries to enhance the process safety performance. This study was performed at the Abu Dhabi Oil National Company (ADNOC) in the UAE. Principal component analysis was used to analyze the response data, resulting in the identification of five safety climate dimensions. Confirmatory factor analysis (CFA) was then performed to test the relationships among the constructs of safety climate dimensions as conceptualized in a measurement model. Finally, a structural model was developed to measure the significance of these five safety climate dimensions in the oil and gas industries in the UAE. This paper confirms the importance of measuring and incorporating multiple factors comprehensively to obtain a complete picture of the implementation and perceptions of safety climate in oil and gas companies in the UAE. It also provides a reliable and validated instrument and first- and second-order models for measuring the safety climate dimensions, which affect the performance of safety in general, and process safety, which is specifically useful for informing practitioner regarding focus area to enhance safety performance.
\end{abstract}

Keywords: safety climate; accidents; oil and gas; structural equation modeling

Reference to this paper should be made as follows: Almazrouei, M, Khalid, K, Davidson, R. 2020. Development and validation of a safety climate scale for United Arab Emirates oil and gas industries to enhance the process safety performance. Entrepreneurship and Sustainability Issues, 7(4), 2863-2882. http://doi.org/10.9770/jesi.2020.7.4(19)

JEL Classificanions: F64, G32, H12, J28

Additional disciplines: Health Safety and Environment

\footnotetext{
${ }^{*}$ The research was supported by Abu Dhabi University, College of Business, United Arab Emirates
} 


\section{ENTREPRENEURSHIP AND SUSTAINABILITY ISSUES}

ISSN 2345-0282 (online) http://jssidoi.org/jesi/

2020 Volume 7 Number 4 (June)

http://doi.org/10.9770/jesi.2020.6.4(19)

\section{Introduction}

Safety performance is indicated by the safety climate. Typically, safety performance can be applied in the prediction of safety results such as occupational injuries or recommended safety behaviors (Meliá et al. 2008, Olsen 2010; Bernardi 2019).

It is essential to apply a validated scale for measuring safety levels accompanied by supporting data (Seo et al. 2004, Yeung and Chan 2012). To realize practical applications of a validity test accompanied by data, organizations have evaluated their safety levels using this verified test. Additionally, the objectives behind this test were to collect quality outcome. Thus, it is evident that the process of assessing reliability is limited to measurement errors of the scale applied (Yeung and Chan 2012).

Despite the efforts by organizations to understand the pillars of safety climate and apply them to their company, an inclusive safety agreement has not been attained. This fact has been proved by evaluation of findings from research that had been previously conducted on commitment levels to establish a common safety platform (Glendon and Litherland 2001, Mohamed 2002, Lu and Shang 2005, Seo 2005, Flin et al. 2006, Evans et al. 2007, Vinodkumar and Bhasi 2009, Chen and Chen 2012). According to one of the safety proposals by Seo et al. (2004) on safety climate dimensions, five categories can be applied in analyzing safety. These include safety support from coworker, supervisor, and commitment levels by management to attain safety standards. Other categories are employees' competence levels, employees' involvement in safety activities, and decision-making when safety climate is in question.

On a related evaluation of outcomes from 18 surveys, Flin et al. (2000) provided six considerations that are always applied to achieve safety climate. These include risk levels, safety of the system, and management involvement. Further, the findings were based on the procedure applied in performing task, competency, and work pressure issues. Moreover, safety rules, safety procedures, supervisory environment, safety training, and safety communication can be also defined as additional dimensions (Lu and Shang 2005, Lin et al. 2008, Tharaldsen et al. 2008, Høivik et al. 2009).

The assessment and validation of measuring instrument have been performed using varied methods. For example, to validate the content obtained, developmental and judgment stages are always taken into considerations (Vinodkumar and Bhasi 2009). Consequently, the developmental stage is managed through conducting critical literature review, while in other cases, research is done in this stage using focused group discussions or interviews. For the judgmental stage to be attained, the qualitative method is applied, and on some occasions, qualitative methods appear the most appropriate where opinion is required (Evans et al. 2007, Høivik et al. 2009). This process is thus found to either focus on literature or panel decision on the most appropriate application.

The content validity of climate safety has been applied by different studies on past findings. The peer previewed outcome on safety climate have always focused their literature review findings on the application of quantitative methods (Mearns et al. 2004, Flin et al. 2006). Only a few panelists have used quantitative methods, thus making it less suitable for safety climate analysis. Another factor that is normally taken into consideration is the validation of instruments (Mohamed 2002). Typically, an expert has preferred using the analysis of exploratory factors followed by a confirmation of the factor analysis applied (Basen-Engquist et al. 1998, Cox and Cheyne 2000, Gershon et al. 2000, Davies et al. 2001). 


\section{ENTREPRENEURSHIP AND SUSTAINABILITY ISSUES}

ISSN 2345-0282 (online) http://jssidoi.org/jesi/

2020 Volume 7 Number 4 (June)

http://doi.org/10.9770/jesi.2020.6.4(19)

Measurement of safety climate has resulted in the development of a number of instruments to be used in different parts of the world. Originally, the first innovation of these instruments was conducted with an objective of developing a safety climate scale in manufacturing companies situated in Iran (Seo 2005). Different scales for measurement of safety climate across parts of the world were influenced by culture contexts, types of industries, sector specifications, and specialization requirements (Hussin et al. 2012). Additionally, procedures for applying these instruments were based on data collected using well-structured questionnaires. Additional considerations were given to scales of measurements and validity and reliability that could be offered.

To attain the desired validity, categories were provided to offer in-depth findings. Among the categories obtained were essentiality, usefulness, and elimination of less useful materials (Huang et al. 2006, Hutchinson et al. 2006). To conduct a parallel study and establish safety climate, this study was developed. A descriptive statistic was thus used for the evaluation and extermination of the content validity of the scale used. Using the expert analysis applied by the panel, various parameters were evaluated (Kho et al. 2005).

The aim of this paper is to investigate and validate the dominant safety climate dimensions in oil and gas industries using principal component analysis (PCA) and confirmatory factor analysis (CFA). The objectives of the present paper are to (i) explore the safety climate dimension in UAE oil and gas industries, (ii) suggest a comprehensive framework for the safety climate dimentions and (iii) investigate and validate the relationships among the dominant safety climate dimensions by introducing first- and second-order CFA models.

The rest of this paper is organized as follows. The section entitled "literature review" reviews the relevant literature aimed at (i) factors affecting safety climate, (ii) major safety accidents around the world and in UAE, and (iii) providing insights into the industry wherein the study was conducted in UAE. The section entitled "Plan and Research Methodology" presents the methodology implemented in the present research. The sections entitled "Data Analysis" and "Discussion and Implications" report and discuss the analysis and findings, whereas the section entitled "Conclusions" concludes the paper.

\section{Literature Review}

\subsection{Background on Process Safety}

Industrial processes at mass scale emerged after the Second World War, resulting in the birth of the safety movement in the early 1960s (Swuste et al. 2016). This crucial movement in the safety domain came to be known as "loss prevention." Following the upscaling of the production processes in the chemical industry, the complexity of controlling such processes increased, leading to toxic substance emissions, fires, and explosions. These incidents had significant impacts on plant premises and beyond. Back then, the public became more anxious about the different forms of pollution and the likelihood of accidents occurring on a large scale (Carson 1962). This was followed by numerous UK and US publications about loss prevention (Fawcett 1959, Association of British Chemical Manufacturers 1964). However, this was subsequent to a series of process accidents and incidents in low-temperature separation and ammonia plants in the early 1950s (Hendershot 2009). The development of process safety has also been affected and influenced by many other global incidents in high-risk process industries, such as the 1986 Chernobyl and 2011 Fukushima nuclear incidents and the 1984 Bhopal and 2005 Texas City petrochemical incidents (Swuste et al. 2016). The article by Kerry that was published in the Chemical Engineering and Processing journal in 1956 triggered dialog during the December 1956 Boston meeting of the American Institute of Chemical Engineers. That meeting culminated in the formation of the "Safety in Air and Ammonia Plants" symposium that began in 1957 and became an annual event going forward (Hendershot 2009). 


\section{ENTREPRENEURSHIP AND SUSTAINABILITY ISSUES}

ISSN 2345-0282 (online) http://jssidoi.org/jesi/

2020 Volume 7 Number 4 (June)

http://doi.org/10.9770/jesi.2020.6.4(19)

\subsection{Factors Affecting Safety Climate}

The concept of a safety climate has various definitions, among which the definition proposed by Zohar (2011) will form the basis of this study . Zohar defined safety climate as the perception behind the practices, procedures, and policies pertaining to safety measures. Zohar's definition covers the holistic aspects of safety climate within an organization and plays an antecedent role in the safety performance of various workplace settings (Griffin and $\mathrm{Hu}$ 2013). The safety climate is strongly related to the perceived risk of accidents and injuries at a workplace (Curcuruto et al. 2015). Therefore, developing a comprehensive safety culture ensures the overall health and safety of the employees working in a specific organization. Safety culture can effectively determine the perceptions, values, attitudes, and overall commitment and proficiency to safety and health management among employees. This information will enable the organization to effectively ensure the well-being of its employees. As such, organizations will focus their efforts on creating mutual trust and shared perceptions with their employees on the benefits of maintaining safety in the workplace (Curcuruto et al. 2015). Obtaining knowledge about the safety culture will enable the organization to arrange possible means of disseminating the correct information to its employees via techniques such as workshop training, whereby they would be educated about the safety measures needed to handle various machines with caution and the importance of wearing protective clothes. Therefore, safety climate enables the organization to acquire particular statistics concerning overall perceptions among employees, effectively limiting their risk by curbing process accidents (Nahrgang et al. 2011).

Safety culture influences the development of process-safety tools used for curbing hazards, disasters, and catastrophes. Based on numerous industrial-incident cases, a strong focus was placed upon the organizational safety culture of various firms with a special emphasis on the existent culture during management of various major hazards. A report by the Baker Panel urged all companies within the industrial field to consider assessing their safety culture and offered important questions to foster discussions of safety climate among employees and their employers and within the refineries of Baker Panel (De Rademaeker et al. 2014). The status of the Baker Panel was such that it inspired more serious consideration of the matter, and the Process Safety Leadership Group has advocated for the development of process-safety programs, focusing more on the growth of safety culture on a positive spectrum (Binch et al. 2012). Considering the high number of reported hazardous cases, it was declared that process-related industries ought to develop climate tools that were solely tailored for process safety. Such tools could determine the messages that were both accessible and inaccessible to workers in hazardous scenarios and those that could nto be accessie as well as the messages that do not get to them. A safety climate would, therefore, facilitate the structuring process of a tool used to reduce the high number of process safety cases.

Researchers and organizations can take decisions regarding safety based on safety climate. The instruments used for assessing safety climate use demographic discrimination among people (Santos et al. 2012). Therefore, the different experiences of different demographics limit the development of a well-informed decision-making system because only the groups with the attained design goals can discern the degree of process-safety culture compared to those who are inadequately informed.

Therefore, the uninformed groups cannot make predictions on the process-safety performance of industries, which in turn leads to disasters. Effects of safety climate on process safety remains understudied, which also considerably contributes to the ignorance of the industry's overall safety culture. This factor incapacitates managers from making the right decision when it comes to processing safety.

Poor decision-making in industries with hazardous content may worsen any directed motives of curbing disasters. It is therefore important for regulated bodies to consider making changes in the way they disseminate their safety climate knowledge and to ensure that each industry is mandated to follow set regulations. In this way, all industries, even those less informed about the safety climate, can include cautionary measures in their processsafety initiatives. Successful installation of the right safety climate procedures and tools will considerably impact 


\section{ENTREPRENEURSHIP AND SUSTAINABILITY ISSUES}

ISSN 2345-0282 (online) http://jssidoi.org/jesi/

2020 Volume 7 Number 4 (June)

http://doi.org/10.9770/jesi.2020.6.4(19)

the safety cultures of organizations. It will only be a matter of time before the number of major disasters is considerably reduced (Santos et al. 2012).

\subsection{Major Accidents around the World and in the UAE}

Many accidents go unreported because of employers' disciplinary programs and employees' fears of reprisal (Fagan and Hodgson 2017). However, some process safety accidents have been quite significant. Examples include the 1974 Flixborough disaster in the UK, the 1984 Bhopal gas tragedy in India, the 1988 Piper Alpha disaster in the North Sea, the 1992 Sodegaura Refinery disaster in Japan, the 2003 DSM chemical plant and 2004 Stockline Plastics explosions in the Netherlands, and the 1989 Phillips 66 Disaster and the 2005 explosion at the Texas City Refinery in the US. These cases from around the world have been reviewed extensively by Okoh and Haugen (Okoh and Haugen 2013).

In the oil and gas industries in the UAE, many safety accidents had been reported. For instance, two incidents occurred at the Abu Dhabi Company's (ADCO) onshore Shah oil field and the Abu Dhabi Gas Liquefaction Company (ADGAS) in February and March 2009, respectively (Carlisle 2009). The Shah field accident claimed three lives and left one worker unconscious during an attempt to drain a transfer line inside the confined space of a corrosion-coupon pit. Moreover, In the March 2009 incident, three employees (a supervisor and two technicians) were hospitalized after an explosion occurred at the Das Island facility. The cause of the explosion was attributed to an electrical discharge (Carlisle 2009).

In 2011, ADNOC, which is a leading fuel distribution company in the UAE and a global leader in the field of oil and gas production and distribution, reported seven significant incidents involving hydrocarbon spills, which resulted in the release of around 4,209 $\mathrm{m}^{3}$ of hydrocarbons (ADNOC Sustainability Report 2011). In the afternoon of October 22, 2015, another incident occurred in the Abu Dhabi industrial area of Mussafah. An explosion was reported following a high-volume leakage of carbon monoxide in the Gulf Piping Company. Although no fatalities were reported, an estimated 11 injuries were reported, of which seven were described as critical (Al Kuttab 2015). In the same year, 20 hydrocarbon spills were reported, of which three were significant, and there were two nonhydrocarbon spills involving chemical solvents. In addition, there were five fatal incidents: two from burns or explosions, two from being struck, and one from a high fall. One fatal incident each was reported from production operations, land transport, inspection testing and maintenance, commissioning/decommissioning in construction, and drilling, workover, and well services (ADNOC Sustainability Report 2015).

On January 11, 2017, a tragic accident involving a fire preceding an explosion occurred at the ADNOC Takreer Refinery (Takreer Incident 2017). This led to the incident being classified as a Tier 1 process safety event, and the company required $\$ 800$ million to restore the unit back to its original operation parameters (Takreer Incident 2017).

\section{Plan and Research Methodology}

This study was undertaken in three major phases (Fig. 1). From the questionnaire information collected, a review of the literature was made, and 662 safety climate items were collected (Koene et al. 2002, Mearns et al. 2003, Wills et al. 2005, 2006, Lu and Tsai 2008, Strahan et al. 2008). Narrowing down to the main objectives and aims of the current study, the number was reduced to 47 after the process of screening. The method used was on the basis of inclusion and exclusion criteria. After that, an exploratory approach to collect empirical data from oil and gas industry companies in the UAE, with specific focus on firms based in Abu Dhabi. In total, 30 health, safety, and environment (HSE) experts working for ADNOC were interviewed. The pool of experts was obtained from both upstream and downstream units. The researcher asked the experts to report on both the external and the internal dimensions that underlie their commitment and desire to adopt, adhere to, and maintain safety climate 
that affect the process safety performance. All responses were filtered, which resulted in the identification of 47 valid safety dimention items within the oil and gas industries in the UAE.

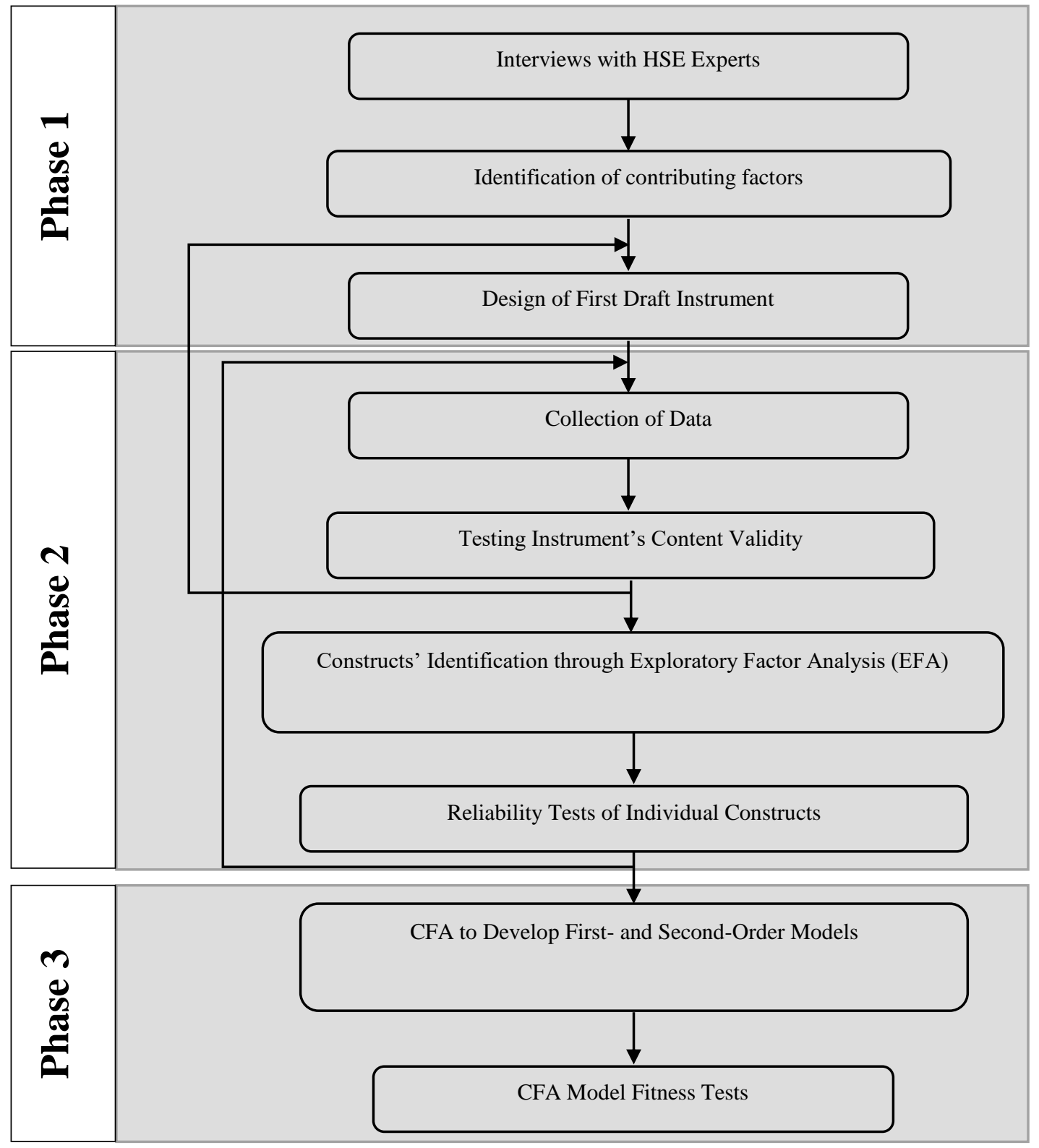

Fig. 1. Research methodology

As illustrated in Fig. 1, the second research phase involved implementing quantitative research methods to generate a pool of items that were included in a scale for measuring the constructs of the safety climate dimentions. This was a critical phase in the research because of the fragmented existing literature on safety climate dimensions. The outcome of this process was a 51-item instrument based on a seven-point Likert scale. A pilot study was conducted to establish the relevance of the first-draft instrument. The main outcome of the pilot study was preliminary validity and reliability information about each measurement scale. Upon completion of this 


\section{ENTREPRENEURSHIP AND SUSTAINABILITY ISSUES}

ISSN 2345-0282 (online) http://jssidoi.org/jesi/

2020 Volume 7 Number 4 (June)

http://doi.org/10.9770/jesi.2020.6.4(19)

phase, SurveyMonkey was used as the platform for administering the final data-collection instrument, and this led to 180 responses from various actors in downstream and upstream units of ADNOC.

\section{Data Analysis}

During the third phase, the 180 responses obtained from the survey were tested. To explain the highest possible common variance with the fewest explanatory constructs (latent variables or factors), PCA was undertaken. These factors denote different highly correlated clusters of safety climate dimensions. A Cronbach's alpha coefficient (Cronbach 1951) of 0.962 affirmed the reliability of the responses for further analysis. Next, the constructs describing the safety climate dimension of the oil and gas industry in the UAE were assessed and validated using CFA.

\subsection{Exploratory Factor Analysis}

Exploratory factor analysis (EFA) was performed during the pilot study phase involving different safety actors, workers, supervisors, and managers in various units and departments. Before proceeding with EFA on the items, some conditions must be satisfied, and this can be assessed through various tests. The Kaiser-Meyer-Olkin (KMO) test (Kaiser 1970) and Bartlett's test of sphericity (Bentler 1992) were among the tests that were performed. As shown in Table 1, the considerably high KMO value (0.955) indicates that the items are appropriate for undertaking factor analysis because no serious multicollinearity issues are indicated within the dataset. Bartlett's test of sphericity (Sig. < 0.01) showed that the interitem correlations were adequate for running factor analysis (Table 1).

Table 1. Results of the KMO test and Bartlett's test of sphericity

\begin{tabular}{llr}
\hline KMO measure of sampling adequacy & & .955 \\
Bartlett's test of sphericity & Approx. Chi & $8,125.709$ \\
& square & 1,081 \\
& df & .000 \\
\hline
\end{tabular}

Subsequent to these two suitability tests, the 51-item instrument was subjected to EFA using PCA as the factor extraction method while varimax rotation was invoked. The factor retention approach was based on the robust combination of theoretical salience, scree plots, and eigenvalues greater than 1.0 for the rotated factors. According to Stevens (Stevens 2009), the ideal situation is for an item to load above 0.40 on its respective factor and below that threshold on any other factor. These resulted 47 -instrument items accounted for $68.27 \%$ of the variance in all responses.

Table 2 shows the rotated component matrix presenting the item loadings and respective factor pattern. The first factor (F1) accounted for a maximum of $51.44 \%$ of the variance in all responses. The questionnaire items that loaded into F1 seem to relate to various aspects of organization commitment to safety (OCS) and safety practices. Thus, F1 was labeled as OCS, and it contained 16 items. The 10 items loading into the second factor (F2) relate to the supervisor commitment to the safety of subordinates. Thus, F2, which accounted for $5.25 \%$ of the variance in all responses, was labeled as supervisor-subordinate commitment to safety (SSCS). The eight factors that loaded into the third factor (F3) accounted for $4.83 \%$ of the variance in all responses. They were mainly about training on safety (TOS), and this led to F3 being labeled as TOS. Six factors loaded into the fourth factor (F4), which explained $3.51 \%$ of the variance in all responses. They all appeared to be about the extent to which the employees were engaged in safety, which informed the labeling of F4 as employee engagement with safety (EES). Finally, 
the fifth factor (F5) accounted for 3.24\% of the variance and contained three items regarding compliance with HSE standards, practices, and procedures. Therefore, F5 was labeled HSE compliance (HSEC).

Table 2. Rotated component matrix

\begin{tabular}{|c|c|c|c|c|c|c|}
\hline Items & & F1 & F2 & F3 & F4 & F5 \\
\hline Q14 & The management ensures reliable and safe equipment & .737 & & & & \\
\hline Q15 & The management eliminates potential safety issues & .736 & & & & \\
\hline Q19 & $\begin{array}{l}\text { My company engages an HSE third-party audit to ensure that } \\
\text { safety rules and regulations are followed }\end{array}$ & .726 & & & & \\
\hline Q2 & $\begin{array}{l}\text { The company maintains records of all first-aid treatments, } \\
\text { inspections, incident investigations, and training activities }\end{array}$ & .726 & & & & \\
\hline Q11 & $\begin{array}{l}\text { The management conducts regular hazard inspections in your } \\
\text { work area }\end{array}$ & .725 & & & & \\
\hline Q18 & My organization enforces a PTW system in all types of work & .712 & & & & \\
\hline Q16 & $\begin{array}{l}\text { The management provides and participates in safety } \\
\text { campaigns }\end{array}$ & .708 & & & & \\
\hline Q9 & $\begin{array}{l}\text { My company provides sufficient personal protective } \\
\text { equipment and gas detectors for the workers }\end{array}$ & 682 & & & & \\
\hline Q8 & $\begin{array}{l}\text { My management encourages raising near misses, unsafe acts, } \\
\text { and unsafe conditions }\end{array}$ & 680 & & & & \\
\hline Q1 & $\begin{array}{l}\text { The management considers safety as a core organizational } \\
\text { value }\end{array}$ & 639 & & & & \\
\hline Q12 & $\begin{array}{l}\text { The management investigates near misses, unsafe acts, and } \\
\text { unsafe conditions in a timely manner }\end{array}$ & .634 & & & & \\
\hline Q5 & $\begin{array}{l}\text { The management considers production to be more important } \\
\text { than safety }\end{array}$ & 631 & & & & \\
\hline Q17 & $\begin{array}{l}\text { My company has clear hydrocarbon and chemical spill } \\
\text { response procedures }\end{array}$ & 625 & & & & \\
\hline Q10 & My company provides enough safety training programs & .612 & & & & \\
\hline Q13 & $\begin{array}{l}\text { The management considers production to be more important } \\
\text { than environmental pollution }\end{array}$ & .578 & & & & \\
\hline Q41 & $\begin{array}{l}\text { The management exercises safety consequences management } \\
\text { standards in case of violation of safety measures }\end{array}$ & .491 & & & & \\
\hline Q26 & My immediate supervisor conducts sufficient toolbox talks & & .817 & & & \\
\hline Q25 & $\begin{array}{l}\text { My immediate supervisor discusses safety issues with others } \\
\text { before performing tasks }\end{array}$ & & .808 & & & \\
\hline Q28 & $\begin{array}{l}\text { My immediate supervisor ensures that the workload and work } \\
\text { patterns are adequate }\end{array}$ & & .760 & & & \\
\hline Q20 & My immediate supervisor enforces safe work behaviors & & .756 & & & \\
\hline Q24 & $\begin{array}{l}\text { My immediate supervisor corrects near misses, unsafe acts, } \\
\text { and unsafe conditions }\end{array}$ & & .707 & & & \\
\hline Q29 & $\begin{array}{l}\text { My immediate supervisor considers human error as part of the } \\
\text { risk assessment }\end{array}$ & & .702 & & & \\
\hline Q27 & My immediate supervisor investigates workplace accidents & & .697 & & & \\
\hline Q21 & $\begin{array}{l}\text { My immediate supervisor cascades the corporate HSE KPIs to } \\
\text { the employees }\end{array}$ & & .677 & & & \\
\hline Q22 & $\begin{array}{l}\text { My immediate supervisor ensures work permits are obtained } \\
\text { and signed }\end{array}$ & & .677 & & & \\
\hline Q23 & $\begin{array}{l}\text { My immediate supervisor ensures that the employees' skills } \\
\text { and abilities match the job tasks }\end{array}$ & & .609 & & & \\
\hline Q43 & $\begin{array}{l}\text { New recruits are trained adequately to learn the safety rules } \\
\text { and procedures }\end{array}$ & & & .634 & & \\
\hline
\end{tabular}




\begin{tabular}{|c|c|c|c|c|c|c|}
\hline Q42 & $\begin{array}{l}\text { My company ensures that contractors are trained to perform } \\
\text { their tasks safely }\end{array}$ & & & .598 & & \\
\hline Q47 & $\begin{array}{l}\text { The safety training given to me is adequate to enable me to } \\
\text { assess hazards in the workplace }\end{array}$ & & & .589 & & \\
\hline Q44 & $\begin{array}{l}\text { The safety training is specific to the job, including hazardous } \\
\text { materials, equipment, noise, fire, and other physical hazards }\end{array}$ & & & .564 & & \\
\hline Q32 & $\begin{array}{l}\text { The safety training includes hazard control measures, such as } \\
\text { department-specific safe operating procedures, acceptable } \\
\text { practices, lock-out/tag-out, and working after hours or alone }\end{array}$ & & & .547 & & \\
\hline Q46 & $\begin{array}{l}\text { The employees' training hours are linked to the overall } \\
\text { performance of my department }\end{array}$ & & & .523 & & \\
\hline Q36 & $\begin{array}{l}\text { The safety training provided is adequate for responses to } \\
\text { emergency seniors and to control safety incidents. }\end{array}$ & & & .500 & & \\
\hline Q33 & $\begin{array}{l}\text { Employees changing jobs or taking extra responsibilities are } \\
\text { trained on the new safety regulations }\end{array}$ & & & .490 & & \\
\hline Q38 & $\begin{array}{l}\text { I feel that my organization is keen on eliminating process } \\
\text { safety incidents }\end{array}$ & & & & .684 & \\
\hline Q37 & $\begin{array}{l}\text { I believe that it is possible to achieve zero process safety } \\
\text { events/incidents in my organization }\end{array}$ & & & & .680 & \\
\hline Q40 & $\begin{array}{l}\text { Employees regularly break the safety rules if they think they } \\
\text { will not get caught }\end{array}$ & & & & .652 & \\
\hline Q39 & Safety professionals are viewed as law enforcement officers & & & & .633 & \\
\hline Q35 & $\begin{array}{l}\text { Safety performance does not improve despite adequate OSHA } \\
\text { compliance, leadership commitment, and training }\end{array}$ & & & & .531 & \\
\hline Q34 & $\begin{array}{l}\text { Employees' participation in safety committees, training, and } \\
\text { other safety-related meetings is low }\end{array}$ & & & & .452 & \\
\hline Q31 & $\begin{array}{l}\text { My organization performs an assessment and audit of } \\
\text { compliance with applicable HSE laws }\end{array}$ & & & & & .843 \\
\hline Q30 & $\begin{array}{l}\text { My organization conducts mock drills to evaluate the } \\
\text { emergency response plan }\end{array}$ & & & & & .816 \\
\hline \multirow[t]{3}{*}{ Q3 } & My organization has HSE measurable performance metrics & & & & & .442 \\
\hline & Average variance extracted $(\%)$ & 51.44 & 5.25 & 4.83 & 3.51 & 3.24 \\
\hline & Construct reliability & .963 & .958 & .935 & .894 & .778 \\
\hline
\end{tabular}

\subsection{Content Validity and Internal Consistency}

Reliability speaks to the magnitude of consistency in the responses pertaining to a respective construct. Normally, Cronbach's alpha is the common measure for these tests. As illustrated in the bottom row of Table 2, the five latent constructs constituted from the contributing factors of safety climate were between 0.778 and 0.963 . The results indicate that the five proposed constructs have good psychometric properties.

\subsubsection{Convergent Validity}

The Bentler-Bonett's normed fit index (NFI) is commonly used for evaluating convergent validity (Bentler 1995). This index shows the extent to which the various approaches employed in measuring a given construct are likely to yield consistent results (Ahire et al. 1996). Bentler (1995) asserted that the rule of thumb is that NFI values of at least 0.90 imply an acceptable fit index. The five constructs had acceptable NFI values, which meant that their constituent items converge well to warrant further analysis, as shown in Table 3. 
Table 3. Construct validity analysis

\begin{tabular}{|l|c|c}
\hline Factors/construct & $\begin{array}{c}\text { Convergent validity } \\
\text { Bentler-Bonett NFI }\end{array}$ & $\begin{array}{c}\text { Discriminant validity } \\
\text { Factor Cronbach's } \alpha \text {-Average correlation between factors }\end{array}$ \\
\hline F1 & .923 & .243 \\
F2 & .977 & .238 \\
F3 & .962 & .215 \\
F4 & .990 & .174 \\
F5 & 1.00 & .058 \\
\hline
\end{tabular}

\subsubsection{Discriminant Validity}

Bagozzi et al. (1991) explained that this type of validity refers to the degree of distinction of distinct latent constructs and their respective indicators from other constructs and indicators.

The computation of discriminant validity involves comparing a latent construct's Cronbach's alpha with its average correlations with the other latent constructs. When the comparison yields a significant difference in the two measures, discriminant validity is confirmed (Ghiselli et al. 1981). The values shown in Table 3 demonstrate a conceptual distinction between the five latent constructs.

\subsection{Confirmatory Factor Analysis}

The EFA led to the identification of OCS, SSCS, TOS, EES, and HSEC as the initial safety climate dimension in the oil and gas industries in the UAE. The first-order model contains OCS, SSCS, TOS, EES, and HSEC as the correlated safety climate factors in the oil and gas industry in the UAE.

The first-order model is shown in Fig. 2. Alternatively, the safety climate factors can be operationalized through a second-order model in which the five constructs of contributing factors are governed by a higher-order factor (i.e., safety climate factors; see Fig. 3). 


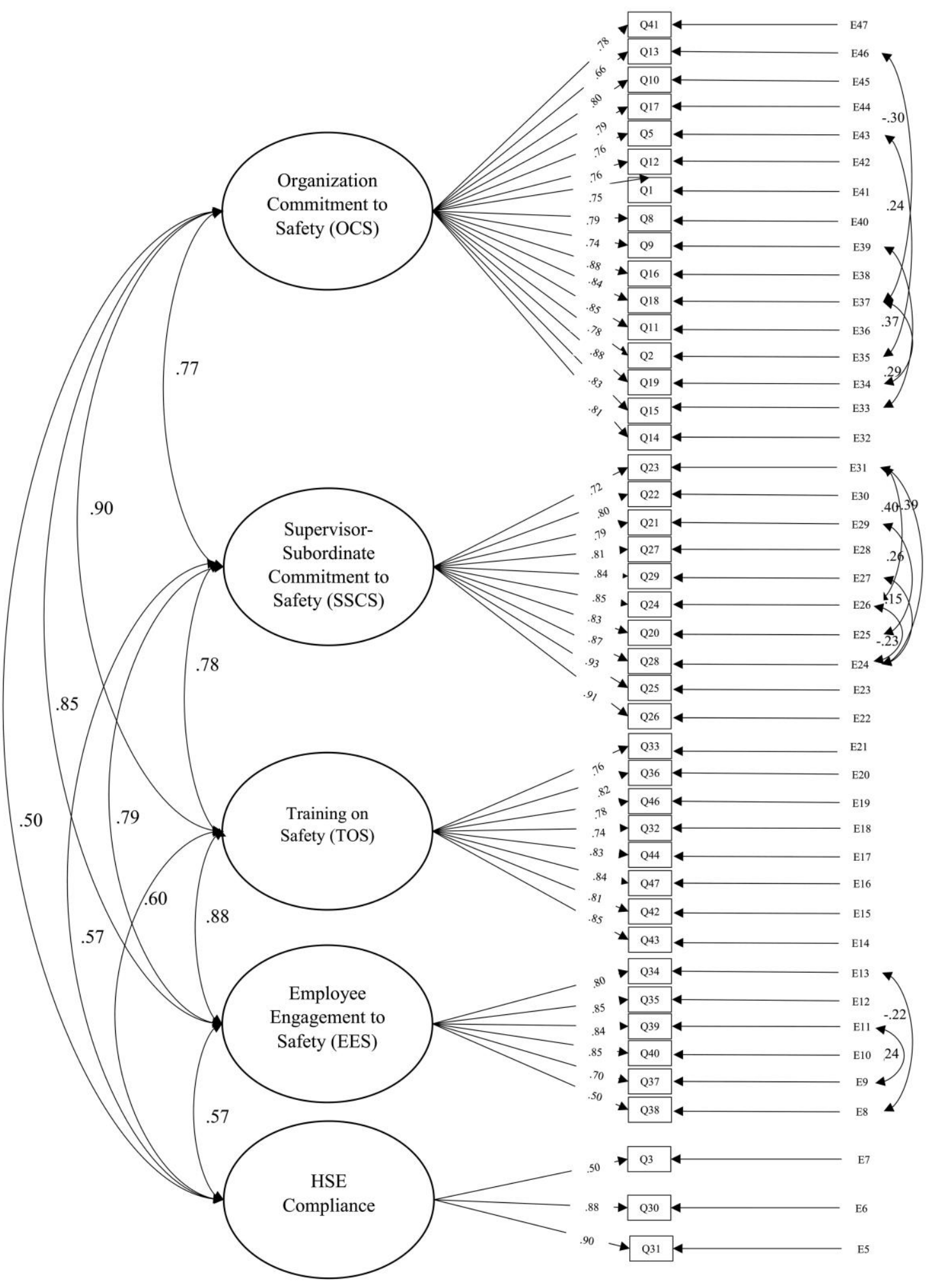

$\mathrm{X}^{2}=1748.356, \mathrm{DOF}=833, \mathrm{CMIN} / \mathrm{DOF}=2.099, \mathrm{CFI}=0.881, \mathrm{TLI}=0.871, \mathrm{RMSEA}=0.078$

Fig. 2. First-order measurement model for safety climate dimensions 


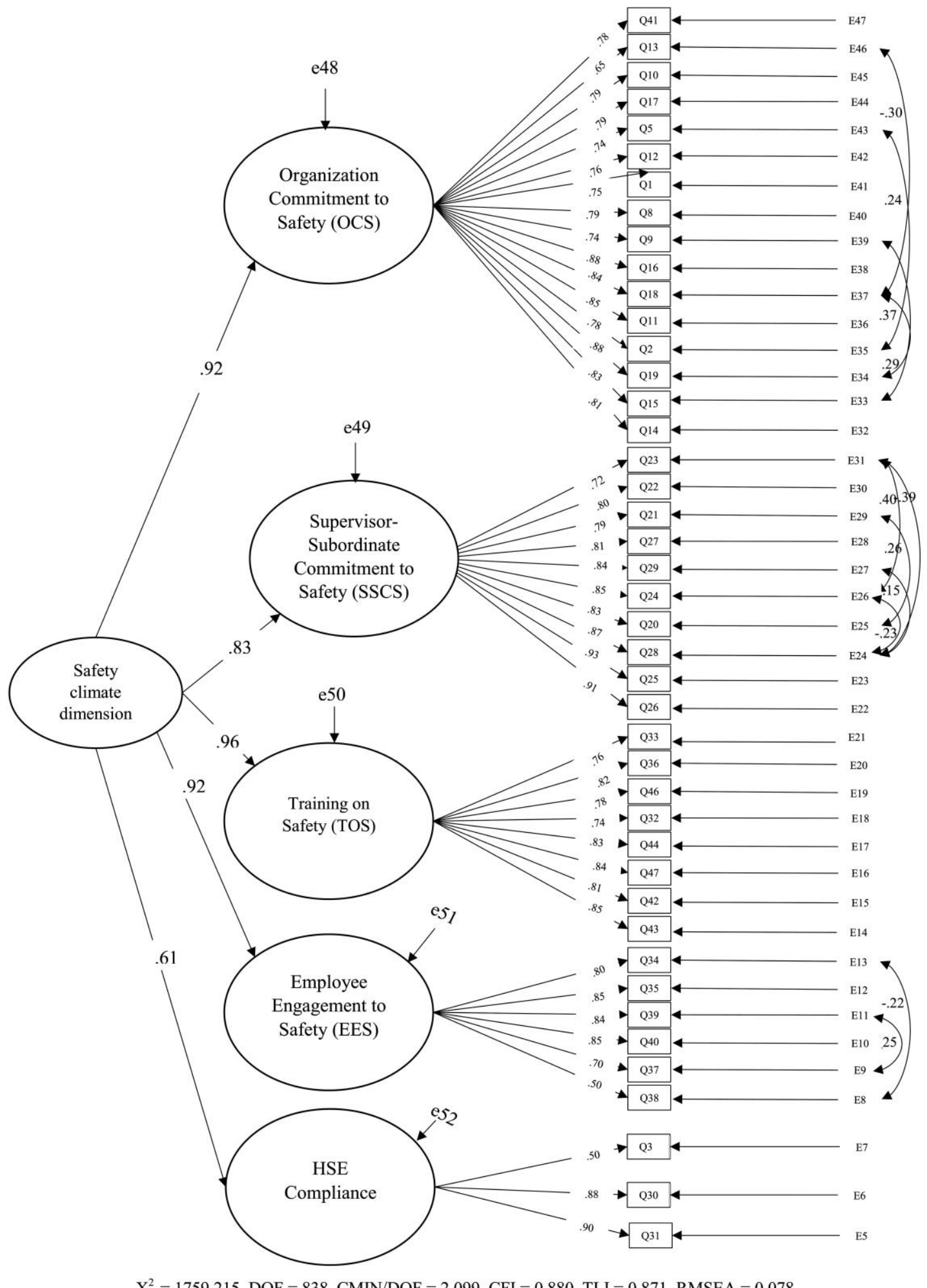

$\mathrm{X}^{2}=1759.215, \mathrm{DOF}=838, \mathrm{CMIN} / \mathrm{DOF}=2.099, \mathrm{CFI}=0.880, \mathrm{TLI}=0.871, \mathrm{RMSEA}=0.078$

Fig. 3. Second-order measurement model for safety climate 


\section{ENTREPRENEURSHIP AND SUSTAINABILITY ISSUES}

ISSN 2345-0282 (online) http://jssidoi.org/jesi/

2020 Volume 7 Number 4 (June)

http://doi.org/10.9770/jesi.2020.6.4(19)

The first-order model for safety climate dimension shown in Fig. 2 implies correlations between OCS, SSCS, TOS, EES, and HSEC, although not under the governance of one shared latent factor. Despite $\chi^{2}$ being statistically significant $(p=0.000)$, the other model-fit indices shown in Fig. 3 back up the first-order model for safety climate dimensions in UAE oil and gas industry .

The results obtained after running the second-order model shown in Fig. 3 indicate that safety climate dimensions as the higher-order latent factor or the overarching trait of safety dimension implementation govern the correlations among OCS, SSCS, TOS, EES, and HSEC. In addition, this second-order model yielded good modelfit indices. Examining the second-order model of safety climate dimension implementation in the oil and gas industries in the UAE reveals the significance of all the coefficient estimates associated with OCS, SSCS, TOS, EES, and HSEC describing the relationships of the five contributing factors on the higher-order construct of safety climate dimension. The results show that TOS had the highest impact on safety climate, whereas HSEC had the lowest impact.

\section{Discussion and Implications}

This study primarily aimed to develop a safety climate scale and validate the scale's reliability. Through this study, 51 items were found to be satisfactory on the developed scale in terms of reliability and validity. However, after a follow-up analysis on EFA and reliability, only 47 items were sufficiently reliable and EFA satisfactory. Using quantitative methods, this study aimed to understand the legitimacy of the content and investigate the validity of the constructed scale using EFA and CFA. Interestingly, the internal-consistency reliability was satisfactory, indicating that the scale is legitimate and dependable for measuring the safety climate. A significant result concerning the relative validity of the safety climate was not acquired herein based on participants' experience with accidents.

Herein, EFA was used to measure the attributes of safety climate in dimensions. Results were then used to label the dimensions of the safety climate as "OCS," "supervisor-subordinate commitment to safety," "training on safety," "employee engagment on safety," and "HSE complaince." Results of this study were similar to those reported previously that recorded the organizational commitment to safety, employee engagment, supervisory committment to safety, training, and audits as factors that infleunced safety performance. An organization's commitment to safety has been described as the fundamental component of safety culture (Flin et al. 2000, Luria and Rafaeli 2008). It manifests in the efforts that are made to ensure that aspects of all organizational operations are adjusted for safety maintenance (Wiegmann et al. 2004). An organization's commitment to safety is judged based on the procedures and equipment of the organization and the employee training and selection (Luria and Rafaeli 2008). This commitment has been shown to be crucial for influencing the way employees perceive, commit to, and ensure a safety culture and to take charge of safety (Morrison and Phelps 1999), resulting in an inclination toward actively taking safety measures (Geller et al. 1996). All effective safety programs require that top management provides a written commitment toward safety, back it up with sufficient resources, provide ongoing training, and fund it adequately (Price and Forrest 2016).

Employee engagement is generally an indispensable contributor to organizational safety. For example, (Harter et al. 2006) found that companies with low employee engagement had over six times more safety incidents than those with higher engagement (Lockwood 2007). found that employees with high engagement had a five times lower likelihood of experiencing safety incidents. They were also seven times less likely to register lost-time safety incidents compared to their nonengaged counterparts. According to (Cooper 2018), employee engagement aims at helping to ensure that employees commit to the values and goals of an organization while motivating them to contribute to the organization's success. The principal aspect is to ensure an understanding that engagement 


\section{ENTREPRENEURSHIP AND SUSTAINABILITY ISSUES}

ISSN 2345-0282 (online) http://jssidoi.org/jesi/

2020 Volume 7 Number 4 (June)

http://doi.org/10.9770/jesi.2020.6.4(19)

entails mutual dialog, leading to joint decision-making while acting together. Employee engagement implies creation of genuine safety partnerships between the workforce and management to enhance safety performance (Cooper 2018). Moreover, supervisors are considered critical role players in showing workers the need to prioritize safety because supervisors inform their subordinates about the types of behavior that are supported and valued within the workplace (Zohar 2002). Their everyday interactions with both management and employees is regarded among the safety climate's building blocks (Bronkhorst et al. 2018). Unsurprisingly, numerous authors have focused on the need to increase the perception that the supervisor is committed to safety (Zohar and Luria 2003, Kines et al. 2010, Zohar and Polachek 2014). In general, results of all these studies have demonstrated that offering feedback and coaching to supervisors on their everyday safety instructions enhanced the perceptions of workers toward prioritizing safety. Supervisory commitment to safety has been shown to predict safety behavior (Taylor and Snyder 2018).

The effect of employee training upon process-safety outcomes has been demonstrated via various industry reports and process-safety literature. However, the most resounding effect has been the revelation that employee training (or the lack of it) has been associated with major process-safety events around the world. For example, the accident that was strongly linked to the lack of employee training with the explosion at BP Texas City resulted in the deaths of 15 individuals and 180 casualties. It was demonstrated that management did not assure the operators' training development for a long time before the process-safety event occurred (Halim and Mannan 2018). Thus, training employees on process safety has been shown to enhance operator performance within the process industry (Nazir and Manca 2015, Yamamoto 2015, Mkpat et al. 2018). However, such training should also be job-specific and extended to new recruits and contractors, as explained in the following three subsections.

Finally, compliance audits are PSM techniques for verifying "that the implementation of the PSM program is in compliance with OSHA standards and to identify potential deficiencies in the PSM program used" (Majid et al. 2014). Such audits have now become integral to implementing safety management in diverse industries because it enables an organization and/or employer to determine the extent to which the 13 PSM components are compliant with the OSHA PSM 29 CFR 1910.119. If the compliance audit is performed as it should be, safety loopholes and weaknesses that could hinder successful maintenance of the facility personnel's safety and of the public around the facility have been identified (Birkmire et al. 2007). Failure to ensure compliance has been linked to the emergence of adverse process-safety accidents such as the Phillips 66 Disaster of 1989 (Okoh and Haugen 2013).

The present paper confirms the importance of measuring and incorporating multiple factors comprehensively to obtain a complete picture of the implementation and perceptions of safety cluture in oil and gas organizations.. Focusing on one construct of safety climate factors even at the item level disregards the potential benefits that are accruable from taking actions that would motivate the organizational stakeholders in all the five construct areas.

These findings demonstrate that oil and gas organizations must adhere to coherent and comprehensive approaches for developing more favorable perceptions toward safety climate in the oil and gas industry. Looking at the second-order model developed in this study from a high-level governing factor to latent constructs, which trickle down to 47 items, provides the foundations of such comprehensiveness and coherence in developing favorable safety climate in oil and gas organizations. 


\section{Conclusions}

\subsection{General Conclusions}

The aims of this paper were to (i) explore the safety climate factors contributing to the reduction of process safety accidents in the oil and gas industry in the UAE and (ii) investigate and validate the relationships among the dominant safety climate contributing factors by introducing first- and second-order CFA. While companies in the oil and gas industries in the UAE have been investing considerable efforts into achieving zero accidents and incidents in their overall operations, evidence shows that they still struggle with eliminating process safety events. Because achieving an effective safety climate in the oil and gas industry entails a collective effort from different stakeholders in an organization and beyond, there are often conflicting perceptions about what works and what does not. The scarcity of an empirically proven and sound research framework for understanding safety climate, which places the various stakeholders and the way they interact within the organization's safety climate framework, makes it more difficult for researchers, managers, and employees to understand the issues that underlie safety climate within this context. In turn, this makes it difficult for oil and gas organizations to implement an effective safety climate successfully both in research and in practice.

\subsection{Limitations and Future Directions for Research}

The framework proposed herein is based mainly on the perspectives of various organizational stakeholders, especially those within the oil and gas industry. The expectation is that the contributing factors of safety climate identified in this paper will be applicable beyond the oil and gas industry and into other complex process-driven industrial sectors such as neuclear industry. Clearly, the proposed framework is an effective and valid instrument for measuring the contributing factors of safety climate. Being knowledgeable about the focus contributing factors of safety climate will aid oil and gas managment in the UAE to foucous more into the safety climate factors to help minimizing process safety accidents.

Despite accomplishing its objectives, this paper was encumbered by some limitations. First, the survey respondents during the primary data-collection phase were drawn from different units of the oil and gas sector. Future studies may also investigate the applicability of the second-order framework to oil and gas sectors outside Abu to other complex process sectors, such as the chemical and neuclear industry. The uniqueness of the oil and gas industries in other emirates (e.g., Dubai) will further help validate and extend the framework developed in this research. In addition, the UAE shares similarities with numerous countries in the Gulf region. Undertaking comparative studies between the oil and gas companies of the UAE and those elsewhere in the Gulf based on the framework proposed in this paper would also be helpful. 


\section{ENTREPRENEURSHIP AND SUSTAINABILITY ISSUES}

ISSN 2345-0282 (online) http://jssidoi.org/jesi/

2020 Volume 7 Number 4 (June)

http://doi.org/10.9770/jesi.2020.6.4(19)

\section{References}

Abdul Majid, N. D., Mohd Shariff, A., \& Mohamed Loqman, S. 2016. Ensuring emergency planning \& response meet the minimum Process Safety Management (PSM) standards requirements. Journal of Loss Prevention in the Process Industries, 40, $248-258$. https://doi.org/10.1016/j.jlp.2015.12.018.

ADNOC Sustainability Report. 2011. Abu Dhabi National oil company 2011 sustainability report. Fostering our society, securing our future. Retrieved from https://www.adnoc.ae/-/media/adnoc/files/publications/adnocsustainabilityreport2011_english.ashx

ADNOC Sustainability Report. 2015. ADNOC group sustainability report 2015: taking innovation to new heights. Retrieved from https://www.adnoc.ae/-/media/adnoc/files/publications/adnoc_sr_main-eng.ashx

Ahire, S. L., Golhar, D. Y., \& Waller, M. A. 1996. Development and validation of TQM implementation constructs, Decision Sciences 27(1), 23-56. http://dx.doi.org/10.1111/j.1540-5915.1996.tb00842.x

Al Kuttab, J. 2015, October 22. Critical injuries after explosion in Abu Dhabi. Khaleej Times, Retrieved from https://www.khaleejtimes.com/nation/abu-dhabi/gas-leak-causes-explosion-in-abu-dhabi

Association of British Chemical Manufacturers. 1964. Safety and management: a guide for the chemical industry. London, UK: Association of British Chemical Manufacturers.

Bagozzi, R. P., Yi, Y., \& Phillips, L. W. 1991. Assessing construct validity in organizational research. Administrative Science Quarterly, 36(3), 421-458. http://dx.doi.org/10.2307/2393203

Basen-Engquist, K., Hudmon, K. S., Tripp, M., \& Chamberlain, R. 1998. Worksite health and safety climate: scale development and effects of a health promotion intervention. Preventive Medicine, 27(1), 111-119. http://dx.doi.org/10.1006/pmed.1997.0253

Bentler, P. 1992. On the fit of models to covariance, Psychological Bulletin 88: 588-606. http://dx.doi.org/10.1037/0033-2909.88.3.588

Bentler, P. M. 1995. EQS structural equations program manual: version 5.0. Encino, CA: Multivariate Software.

Bernardi, A. 2019. The capability approach and organizational climate as tools to study occupational health and safety. Insights into Regional Development, 1(2), 155-169. https://doi.org/10.9770/ird.2019.1.2(6)

Binch, S., Sugden, C., Healey, N., \& Lekka, C. B. 2012. Developing a process safety climate tool: the long and winding road.

Bird, F. and Loftus, R.G. 1974. Loss Control Management, Institute Press, Georgia

Birkmire, John C., Lay, James R., \& McMahon, Mona C. 2007. Keys to effective third-party process safety audits. Journal of Hazardous Materials, 142(3), 574-581. http://dx.doi.org/10.1016/j.jhazmat.2006.06.065

Bronkhorst, B., Tummers, L. \& Steijn, B. 2018. Improving safety climate and behavior through a multifaceted intervention: Results from a field experiment. Safety Science, 103, 293-304

Carlisle, T. 2009. Three injured in explosion. Retrieved from https://www.thenational.ae/business/three-injured-in-explosion-1.492593

Carson, R. 1962. Silent spring. Boston, MA: Houghton Mifflin.

Chen, C.-F., \& Chen, S.-C. 2012. Scale development of safety management system evaluation for the airline industry. Accident Analysis \& Prevention, 47, 177-181. http://dx.doi.org/10.1016/j.aap.2012.01.012

Cooper, M. D. (2018). The Safety Culture Construct: Theory and Practice. Safety Cultures, Safety Models Springer Briefs in Applied Sciences and Technology, 47-61. http://dx.doi.org/10.1007/978-3-319-95129-4_5

Cox, S. J., \& Cheyne, A. J. T. 2000. Assessing safety culture in offshore environments. Safety Science, 34(1-3), 111-129. http://dx.doi.org/10.1016/s0925-7535(00)00009-6 


\section{ENTREPRENEURSHIP AND SUSTAINABILITY ISSUES}

ISSN 2345-0282 (online) http://jssidoi.org/jesi/

2020 Volume 7 Number 4 (June)

http://doi.org/10.9770/jesi.2020.6.4(19)

Cronbach, L. J. 1951. Coefficient alpha and the internal structure of tests. Psychometrika, 16(3), 297-334. http://dx.doi.org/10.1007/bf02310555

Curcuruto, M., Conchie, S. M., Mariani, M. G., \& Violante, F. S. 2015. The role of prosocial and proactive safety behaviors in predicting safety performance. Safety Science, 80, 317-323. http://dx.doi.org/10.1016/j.ssci.2015.07.032

Davies, F., Spencer, R., \& Dooley, K. 2001. Summary guide to safety climate tools. Norwich, UK: HSE Books.

De Rademaeker, E., Suter, G., Pasman, H. J., \& Fabiano, B. 2014. A review of the past, present and future of the European loss prevention and safety promotion in the process industries. Process Safety and Environmental Protection, 92(4), $280-291$. http://dx.doi.org/10.1016/j.psep.2014.03.007

Evans, B., Glendon, A. I., \& Creed, P. A. 2007. Development and initial validation of an aviation safety climate scale. Journal of Safety Research, 38(6), 675-682. http://dx.doi.org/10.1016/j.jsr.2007.09.005

Fagan, K. M., \& Hodgson, M. J. 2017. Under-recording of work-related injuries and illnesses: an OSHA priority. Journal of Safety Research, 60, 79-83. http://dx.doi.org/10.1016/j.jsr.2016.12.002

Fawcett, H. H. 1959. SAFETY-chemical booby traps. Industrial \& Engineering Chemistry, 51(4), 89A-90A. http://dx.doi.org/10.1021/ie50592a013

Flin, R., Burns, C., Mearns, K., Yule, S., \& Robertson, E. M. 2006. Measuring safety climate in health care. Quality \& Safety in Health Care, 15(2), 109-115. http://dx.doi.org/10.1136/qshc.2005.014761

Flin, R., Mearns, K., O'Connor, P., \& Bryden, R. 2000. Measuring safety climate: identifying the common features. Safety Science 34(1-3): 177-192. http://dx.doi.org/10.1016/s0925-7535(00)00012-6

Geller, E. S., Roberts, D. S., \& Gilmore, M. R. (1996). Predicting propensity to actively care for occupational safety. Journal of Safety Research, 27(1), 1-8. https://doi.org/10.1016/0022-4375(95)00024-0

Gershon, R. R. M., Karkashian, C. D., Grosch, J. W., Murphy, L. R., Escamilla-Cejudo, A., Flanagan, P. A., Bernacki, E., Kasting, C., \& Martin, L. 2000. Hospital safety climate and its relationship with safe work practices and workplace exposure incidents. American Journal of Infection Contro, 28(3), 211-221. http://dx.doi.org/10.1067/mic.2000.105288

Ghiselli, Edwin E., John P. Campbell, and Sheldon Zedeck. 1981. Meaurement Theory for the Behavioral Sciences. San Fransisco: W.H. Freeman and Company.

Glendon, A. I., \& Litherland, D. K. 2001. Safety climate factors, group differences and safety behaviour in road construction. Safety Science, 39(3), 157-188. http://dx.doi.org/10.1016/s0925-7535(01)00006-6

Halim S.Z., Mannan M.S., 2018, A journey to excellence in process safety management, Journal of Loss Prevention in the Process Industries, 55, 71-79.

Harter, J. K., \& Schmidt, F. L. (2006). Connecting employee satisfaction to business unit performance. In A. I. Kraut (Ed.), Getting action from organizational surveys: New concepts, technologies, and applications (pp. 33-52). San Francisco: Jossey-Bass.

Hendershot, D. C. 2009. A history of process safety and loss prevention in the American institute of chemical engineers. Process Safety Progress, 28(2), 105-113. http://dx.doi.org/10.1002/prs.10318

Høivik, D., Tharaldsen, J. E., Baste, V., \& Moen, B. E. 2009. What is most important for safety climate: the company belonging or the local working environment?-A study from the Norwegian offshore industry. Safety Science, 47(10), 1324-1331. http://dx.doi.org/10.1016/j.ssci.2009.04.001

Huang, Y.-H., Ho, M., Smith, G. S., \& Chen, P. Y. 2006. Safety climate and self-reported injury: assessing the mediating role of employee safety control. Accident Analysis \& Prevention, 38(3), 425-433. http://dx.doi.org/10.1016/j.aap.2005.07.002

Hussin, M. F., Wang, B., \& Hipnie, R. 2012. The reliability and validity of basic offshore safety and emergency training knowledge test. Journal of King Saud University - Engineering Sciences, 24(2), 95-105. http://dx.doi.org/10.1016/j.jksues.2011.05.002 


\section{ENTREPRENEURSHIP AND SUSTAINABILITY ISSUES}

ISSN 2345-0282 (online) http://jssidoi.org/jesi/

2020 Volume 7 Number 4 (June)

http://doi.org/10.9770/jesi.2020.6.4(19)

Hutchinson, A., Cooper, K. L., Dean, J. E., McIntosh, A., Patterson, M., Stride, C. B., Laurence, B. E., \& Smith, C. M. 2006. Use of a safety climate questionnaire in UK health care: factor structure, reliability and usability. Quality and Safety in Health Care, 15(5), 347-353. http://dx.doi.org/10.1136/qshc.2005.016584

Kho, M. E., Carbone, J. M., Lucas, J., \& Cook, D. J. 2005. Safety climate survey: reliability of results from a multicenter ICU survey. Quality and Safety in Health Care, 14(4), 273-278. http://dx.doi.org/10.1136/qshc.2005.014316.

Kines, P., et al., 2010. Improving construction site safety through leader-based verbal safety communication. Journal of safety research, 41(5), 399-406. Available from: http://search.proquest.com/docview/756307296?accountid=14468

Koene, B. A. S., Vogelaar, A. L. W., \& Soeters, J. L. 2002. Leadership effects on organizational climate and financial performance. The Leadership Quarterly, 13(3), 193-215. http://dx.doi.org/10.1016/s1048-9843(02)00103-0

Lin, S.-H., Tang, W.-J., Miao, J.-Y., Wang, Z.-M., \& Wang, P.-X. 2008. Safety climate measurement at workplace in China: a validity and reliability assessment. Safety Science, 46(7), 1037-1046. http://dx.doi.org/10.1016/j.ssci.2007.05.001.

Lockwood, N.R. (2007) Leveraging Employee Engagement for Competitive Advantage. Society for Human Resource Management Research Quarterly, 1, 1-12.

Lu, C.-S., \& Shang, K.-C. 2005. An empirical investigation of safety climate in container terminal operators, Journal of Safety Research 36(3): 297-308. http://dx.doi.org/10.1016/j.jsr.2005.05.002

Lu, C.-S., \& Tsai, C.-L. 2008. The effects of safety climate on vessel accidents in the container shipping context. Accident Analysis \& Prevention, 40(2), 594-601. http://dx.doi.org/10.1016/j.aap.2007.08.015.

Luria, G., \& Rafaeli, A. (2008). Testing safety commitment in organizations through interpretations of safety artifacts. Journal of Safety Research, 39, 519-528. http://dx.doi.org/10.1016/j.jsr.2008.08.004

Mearns, K., Rundmo, T., Flin, R., Gordon, R., \& Fleming, M. 2004. Evaluation of psychosocial and organizational factors in offshore safety: a comparative study. Journal of Risk Research, 7(5), 545-561. http://dx.doi.org/10.1080/1366987042000146193

Mearns, K., Whitaker, S. M., \& Flin, R. 2003. Safety climate, safety management practice and safety performance in offshore environments,. Safety Science, 41(8), 641-680. http://dx.doi.org/10.1016/s0925-7535(02)00011-5

Meliá, J. L., Mearns, K., Silva, S. A., \& Lima, M. L. 2008. Safety climate responses and the perceived risk of accidents in the construction industry. Safety Science, 46(6), 949-958. http://dx.doi.org/10.1016/j.ssci.2007.11.004

Mkpat E., Reniers G., Cozzani V., 2018, Process safety education: A literature review. Journal of Loss Prevention in the Process Industries, 54, 18-27.

Mohamed, S. 2002. Safety climate in construction site environments. Journal of Construction Engineering and Management, 128(5), 375384. http://dx.doi.org/10.1061/(asce)0733-9364(2002)128:5(375)

Morrison, E. W., \& Phelps, C. C. (1999). Taking charge at work: Extrarole efforts to initiate workplace change. Academy of Management Journal, 42(4), 403-419.

Nahrgang, J. D., Morgeson, F. P., \& Hofmann, D. A. 2011. Safety at work: a meta-analytic investigation of the link between job demands, job resources, burnout, engagement, and safety outcomes. Journal of Applied Psychology, 96(1), 71-94. http://dx.doi.org/10.1037/a0021484

Nazir, S., Manca, D. (2015). How a plant simulator can improve industrial safety. Process Safety Progress, 34 (3), $237-243$.

Okoh, P., \& Haugen, S. 2013. The influence of maintenance on some selected major accidents. CET Chemical Engineering Transactions, 31, 493-498.

Olsen, E. 2010. Exploring the possibility of a common structural model measuring associations between safety climate factors and safety behaviour in health care and the petroleum sectors. Accident Analysis \& Prevention, 42(5), 1507-1516. http://dx.doi.org/10.1016/j.aap.2010.02.002 


\section{ENTREPRENEURSHIP AND SUSTAINABILITY ISSUES}

ISSN 2345-0282 (online) http://jssidoi.org/jesi/

2020 Volume 7 Number 4 (June)

http://doi.org/10.9770/jesi.2020.6.4(19)

Price, J. C., \& Forrest, J. S. 2016. Practical airport operations, safety, and emergency management: protocols for today and the future. Amsterdam: Elsevier.

Santos, A., Hayward, T., \& Ramos, H. M. 2012. Organizational culture, work and personal goals as predictors of employee well-being. Journal of Organizational Culture, Communications and Conflict, 16(1), 25

Seo, D.-C. 2005. An explicative model of unsafe work behavior. Safety Science, 43(3), 187-211. http://dx.doi.org/10.1016/j.ssci.2005.05.001

Seo, D.-C., Torabi, M. R., Blair, E. H., \& Ellis, N. T. 2004. A cross-validation of safety climate scale using confirmatory factor analytic approach. Journal of Safety Research, 35(4), 427-445. http://dx.doi.org/10.1016/j.jsr.2004.04.006

Stevens, J. P. 2009. Applied multivariate statistics for the social sciences. New York, NY: Routledge.

Strahan, C., Watson, B., \& Lennonb, A. 2008. Can organisational safety climate and occupational stress predict work-related driver fatigue? Transportation Research Part F: Traffic Psychology and Behaviour, 11(6), 418-426. http://dx.doi.org/10.1016/j.trf.2008.04.002

Swuste, P., Theunissen, J., Schmitz, P., Reniers, G., \& Blokland, P. 2016. Process safety indicators, a review of literature. Journal of Loss Prevention in the Process Industries, 40, 162-173. http://dx.doi.org/10.1016/j.jlp.2015.12.020

Swuste, P., van Gulijk, C., Zwaard, W., Lemkowitz, S., Oostendorp, Y., \& Groeneweg, J. 2016. Developments in the safety science domain, in the fields of general and safety management between 1970 and 1979, the year of the near disaster on Three Mile Island, a literature review. Safety Science, 86, 10-26. http://dx.doi.org/10.1016/j.ssci.2016.01.022

Takreer Incident. 2017. Ruwais refinery west-fire and explosion incident. Retrieved from https://www.scribd.com/document/361596465/Ruwais-Refinery-West-Rrw-Fire-Explosion-Incident.

Taylor, W.D., \& Snyder, L.A. 2017. The influence of risk perception on safety: A laboratory study. Safety Science, 95, 116-124.

Tharaldsen, J. E., Olsen, E., \& Rundmo, T. 2008. A longitudinal study of safety climate on the Norwegian continental shelf. Safety Science, 46(3), 427-439. http://dx.doi.org/10.1016/j.ssci.2007.05.006

Vinodkumar, M. N., \& Bhasi, M. 2009. Safety climate factors and its relationship with accidents and personal attributes in the chemical industry. Safety Science, 47(5), 659-667. http://dx.doi.org/10.1016/j.ssci.2008.09.004

Wiegmann, D.A. et al., 2004. Safety culture: an integrative review. International Journal of Aviation Psychology, 14(2), $117-134$.

Wills, A. R., Biggs, H. C., \& Watson, B. 2005. Analysis of a safety climate measure for occupational vehicle drivers and implications for safer workplaces. The Australian Journal of Rehabilitation Counselling, 11(1), 8-21. http://dx.doi.org/10.1017/s1323892200000132

Wills, A. R., Watson, B., \& Biggs, H. C. 2006. Comparing safety climate factors as predictors of work-related driving behavior. Journal of Safety Research, 37(4), 375-383. http://dx.doi.org/10.1016/j.jsr.2006.05.008

Yamamoto, S. (2015). A systematic knowledge education approach for safety-critical system development. Procedia Computer Science, 60,960-967

Yeung, K.-C., \& Chan, C. C. 2012. Measuring safety climate in elderly homes. Journal of Safety Research, 43(1), 9-20. http://dx.doi.org/10.1016/j.jsr.2011.10.009

Zohar, D. (2002). Modifying supervisory practices to improve subunit safety: A leadership-based intervention model. Journal of Applied Psychology, 87(1), 156-163. https://doi.org/10.1037/0021-9010.87.1.156

Zohar, D. 2011. Safety climate: conceptual and measurement issues, in Quick, J. C. \& Tetrick, L. E. (Eds.), Handbook of occupational health psychology. Washington, DC: American Psychological Association, 141-164.

Zohar, D., \& Luria, G. (2003). The use of supervisory practices as leverage to improve safety behavior: A cross-level intervention model. Journal of Safety Research, 34(5), 567-577. http://dx.doi.org/10.1016/j.jsr.2003.05.006 


\section{ENTREPRENEURSHIP AND SUSTAINABILITY ISSUES}

ISSN 2345-0282 (online) http://jssidoi.org/jesi/

2020 Volume 7 Number 4 (June)

http://doi.org/10.9770/jesi.2020.6.4(19)

Zohar, D., \& Polachek, T. (2014). Discourse-based intervention for modifying supervisory communication as leverage for safety climate and performance improvement: A randomized field study. Journal of Applied Psychology,99(1), 113-124. http://dx.doi.org/10.1037/a0034096

\section{Acknowledgements}

The research was supported by Abu Dhabi University, College of Business, United Arab Emirates

Mohamed ALI ALMAZROUEI holds a master degree in Business Adminstration and is currently a DBA student at College of Business, Abu Dhabi University, United Arab Emirates. His research interests are in the areas of understanding process safety in the modern process industry: psychometric properties and relationship with safety culture.

ORCID ID: https://orcid.org/0000-0002-1077-6123

Khalizani KHALID holds a Ph.D. in Business Administration and she is presently an assistant professor at College of Business, Abu Dhabi University UAE. Her research interest includes human resource management, behavioral decision-making, sustainability, technology management, and vocational education.

ORCID ID: https://orcid.org/0000-0002-8485-1616

Ross DAVIDSON received his PhD in international HR managment and he is presently an assistant professor at College of Business, Abu Dhabi University, UAE. His research interests focus on the co-creation of safety, international human resource management, organizational learning in the international setting, and leadership.

ORCID ID: https://orcid.org/0000-0002-9765-4865

Copyright (C) 2020 by author(s) and VsI Entrepreneurship and Sustainability Center

This work is licensed under the Creative Commons Attribution International License (CC BY).

http://creativecommons.org/licenses/by/4.0/

(c) () Open Access 